\title{
Entre la oralidad y la escritura: una poética del poder en Yo el Supremo, de Augusto Roa Bastos
}

\author{
Between orality and writing: a poetics of power in \\ Yo el Supremo, by Augusto Roa Bastos
}

Flor Esther Aguilera Navarrete

ORCID: 0000-0003-0890-3397

Universidad de Guanajuato, México.

flor.aguilera@ugto.mx

Resumen:

En el presente artículo se reflexiona sobre la lucha de poder que se configura en Yo el Supremo (1974), del escritor paraguayo Augusto Roa Bastos, a través de la oralidad y la escritura, siguiendo como marco metodológico, principalmente, los estudios de Mijaíl Bajtín y Ángel Rama. Con dicha dicotomía se plantea la relación de tensión entre la presencia conflictiva del guaraní, lengua relegada a la condición de oralidad, y el uso del español, lengua símbolo de colonización y dominio, para explicar que Yo, el Supremo presenta una crítica mordaz a cómo la cultura nativa del Paraguay se ha relegado. Ello evidencia un discurso transgresor, destinado a romper el canon, la escritura oficial que, según la novela, se ha impuesto por la dominación escrituraria.

Palabras clave:

oralidad, escritura, dicotomía, colonización, discurso transgresor, crítica social. 
Abstract:

This article aims to reflect on the power struggle that is configured in I the Supreme (1974), of the Paraguayan writer Augusto Roa Bastos, through orality and writing, mainly following the studies of Mijail Bajtin and Angel Rama as the methodological framework. The oral and written dichotomy creates tension between the conflicting presence of Guarani language, relegated to the condition of orality, and Spanish, a language that is symbol of colonization and domination, in order to explain that I, the Supreme presents a scathing critique of how the native culture of Paraguay has been relegated. This evidences a transgressor speech that is meant to break canon, the official writing that according to the novel, has been imposed by the scriptural domination.

Keywords:

Orality, Writing, Dichotomy, Colonization, Transgressive speech, Social criticism.

DOI: https://doi.org/10.36798/critlit.vi22.328

Recibido: 11 de enero de 2020

Aceptado: 18 de enero de 2021

Encerrar hechos de naturaleza en signos de contranatura. Augusto Roa Bastos

Escribir no significa convertir lo real en palabras sino hacer que la palabra sea real. Augusto Roa Bastos

El mundo no cabe en la palabra que lo representa. Mijaíl Bajtín 


\section{Introducción}

El presente artículo de investigación tiene por interés reflexionar sobre la novela Yo el Supremo, de Augusto Roa Bastos (1917-2005), publicada en Buenos Aires en 1974 durante el exilio político del autor. Dicha obra es considerada un referente de la literatura de finales del siglo XX de América Latina, ${ }^{1}$ no solo por su técnica narrativa de vanguardia, sino por la relevante discusión que realiza en torno al poder político, al poder de la Dictadura y al poder escriturario siempre en confrontación con la oralidad. En efecto, Yo el Supremo no es una novela fácil, su estructura compleja requiere de muchas reflexiones, de muchos intentos por llegar a la profundidad del mensaje, al meollo del símbolo. Sin embargo, tampoco es una novela encriptada, destinada solo a intelectuales de academia. Más bien, se trata de una novela exigente, que requiere de un lector comprometido con el acto escriturario y con el hecho interpretativo. En este sentido, se intentará escudriñar dicha novela para entender la relación existente entre la oralidad y la escritura, con el objeto de comprender una poética de la escritura, que es, en términos roabastianos, una poética del poder (político y escriturario). Con esta idea,

${ }^{1}$ Juan Manuel Marcos señala que Yo el Supremo es una de las manifestaciones más audaces del Neobarroquismo de la narrativa latinoamericana (41). Fernando de Burgos apunta que si Yo el Supremo es un referente es debido a su principio de desescribir la escritura de la convención, ser crítica de la propia escritura: la literaria e histórica. Por su parte, Silvia Pappe comenta que esta novela trasciende porque en realidad no se trata de una revolución política sino lingüística,que desafía y desconfía del poder invasor cultural de las sociedades centrales, ese poder represor que se encarga de escribir la historia del pasado. Luis Alfredo Velasco Guerrero afirma que si esta novela es piedra angular en la evolución del género de la Novela Histórica Latinoamericana es debido a las diversas unidades estilísticas heterogéneas que se combinan en ella, ofreciendo un discurso descentralizado, donde la historia y la literatura se evidencian como un proceso complejo, intertextual y heterogéneo. Sin embargo, Rosa María Burrola Encinas argumenta que las aportaciones de Roa Bastos a la Nueva Novela Hispanoamericana no deben buscarse desde Yo el Supremo, sino desde finales de los años cuarenta, cuando publica Hijo de hombre (1959). 
se buscará comprender la crítica que hace Roa Bastos con respecto a la realidad histórica de Paraguay, su país de origen (por supuesto, realidad no muy distinta a la de toda América Latina), evidenciando y reflexionando los problemas a los que históricamente se han enfrentado los nativos de esas tierras y, en particular, los guaraníes que habitan el territorio paraguayo.

En esta novela, la escritura (representada por el castellano como símbolo de dominación) y la oralidad (representada por el guaraní como símbolo de dominado) será, entonces, una dicotomía con la cual Roa Bastos denuncia las décadas de sufrimiento del pueblo paraguayo, poniendo énfasis, además, en la aculturación (en términos de Ángel Rama), que no es otra cosa que la negación o pérdida de la cultura propia. Así, este trasfondo de crítica histórico-social será, al mismo tiempo, un proyecto literario, donde ambos sistemas de pensamiento, oralidad-guaraní y escritura-castellano, se confrontan, cuestionan sus propios límites, intentan subsanar una deuda histórica con la cultura nativa, provocando un mestizaje consciente, una transculturación y no una aculturación, donde exista una verdadera fusión de lenguas, de sistemas de pensamientos, de culturas, de historia mutua, de reflexión ontológica social. La propuesta de la novela es, precisamente, hacer del espacio de ficción un medio de reconciliación. No obstante, todo será un fracaso, por ello el personaje principal, el Supremo, encontrará su desgracia eterna. Roa Bastos explica este hecho:

Pero, en sentido más profundo, hay también una ambigua e indiscernible constricción ideológica inherente al empleo de la lengua culta: el escritor, el narrador, el novelista, al optar por la escritura en castellano (opción por otra parte normal puesto que la lengua culta y escritura se corresponde como estructuras simétricas en oposición al concepto de literatura oral y popular cuyos medios son completamente diferentes); al elegir el narrador la escritura en castellano asume consciente o inconscientemente el rol, la posición ideológica de la cultura y de la lengua dominante. (Augusto Roa Bastos y la producción 131-132) 
Por otro lado, señala Julio Ortega, está la idea de que "en América Latina, o el lenguaje mismo, es a veces incapaz de dar cuenta del exceso de realidad" (63), con lo que se quiere decir que la noción de los límites del mundo no son los del lenguaje, que la realidad siempre supera y superará a la literatura.

De esta forma, Yo el Supremo se manifiesta como paradigma de la narrativa de fines de siglo XX, pues el proyecto estético que se enfatiza en ella implica una transformación, un desencanto por los relatos utópicos, una emancipación y reivindicación de la literatura hispanoamericana que se escribía hasta entonces, como el criollismo, el nativismo, el regionalismo, el indigenismo o el negrismo. Más bien, debido a su peculiaridad discursiva, se propone una novela mosaico, collage, ensamblaje, interrogativa de sí misma, el tipo de novela que Mijaíl Bajtín llamó descentralizada, polifónica o centrífuga. Para argumentar nuestras posturas tendremos como marco metodológico, principalmente, Teoría y estética de la novela, de Mijaíl Bajtín; Transculturación narrativa en América Latina y La ciudad letrada, de Ángel Rama; y Oralidad escrita. Sobre la reivindicación y re-inscripción del discurso oral (1997), de Jorge Marcone.

Adriana Sandoval ubica a Yo el Supremo dentro del grupo de novelas sobre dictadores, las cuales son identificadas con la llamada Nueva Novela Histórica que se produjo durante el boom (periodo también llamado nueva novela o novela vanguardista) o posboom (conocido académicamente como novísima novela o novela posvanguardista) en Latinoamérica. Sin embargo, esta pieza literaria es más que una novela histórica sobre dictadores, en este caso sobre el dictador Dr. José Gaspar Rodríguez de Francia (1811 a 1840), ya que en realidad solo es el pre-texto ${ }^{2}$ para ahondar sobre temas filosóficos acerca de la escritura y la oralidad. En ella no hay una fábula o historia precisa, es decir, no hay una configuración de la trama, al menos no en un sentido tradicional. Es un montaje de varios documentos, ${ }^{3}$ donde

2 Usamos "pre-texto" en doble sentido: como motivo o excusa y como alusión a un texto previo (bipotexto) referente.

${ }^{3}$ Milagros Ezquerro, en el estudio preliminar de Yo el Supremo, les llama modalidades narrativas. 
se supone que el Supremo dejó escrita la historia del Estado paraguayo, así como sus reflexiones íntimas, que fueron salvados de ser quemados por el pueblo, razón por la cual, en muchas partes de la novela, ese actuar y decir de los personajes no se completa, ya que fueron tragados por el fuego. Este hecho será de mucha importancia para la construcción de la poética de la escritura, puesto que al aparecer en escena el decir de los personajes como algo incompleto, simboliza la incapacidad de la escritura para trascender en el mundo de la cultura de un pueblo. Después de ser salvados y analizados estos documentos, el Compilador (quien entre líneas sabemos que se apellida Roa Bastos) inicia la escritura de la biografía del Supremo para, posteriormente, editarla. En el transcurso de este proceso, el Supremo comienza a tener conciencia de sí mismo, se revela contra el Compilador y comienza a cuestionarlo sobre su supuesta labor de rescate histórico. Así se inicia una reflexión acerca de lo que significa la historia, los documentos historiográficos, el pasado, la memoria, la oralidad y la escritura. Pero el Supremo, al ser autoconsciente, sabe que está muerto, que pertenece al pasado, que solo es una ilusión, una invención, una artificialidad, como la escritura misma. Así, la estructura novelística se compone de una doble dimensión de realidad: la del Compilador y la del Supremo, que se encuentran en conflicto constante, en relación problemática, lo que provoca ambigüedades o contradicciones en el espacio narrativo. En cada dimensión de realidad, el narrador tiene un objetivo distinto, pero con puntos trascendentes de encuentro. Ambos narradores, en toda la novela, crean un juego de dobles donde se involucran los deícticos Yo/Él, simbolizando cada uno las figuras narrativas. El Yo representa al Compilador: la figura privada, oculta, con objetivos muy personales, interiores o profundos (literarios), que a su vez simbolizará la escritura. El Él representa al Supremo: la figura pública, descubierta, con objetivos más que personales históricos, de intereses más externos o colectivos que individuales, que a su vez simbolizará la oralidad. Al respecto, escribe Bajtín: "La literatura crea las imágenes muy específicas de las personas, en las cuales el yo y el otro se combinan de un modo especial e irrepetible: el yo en forma de otro, o bien el otro en forma de un yo" (Yo también 166). Es 
una con-fusión simbólica de imágenes que se evidencian en la novela, por ello de forma constante ambas figuras deícticas se fusionan.

La dimensión de realidad del Compilador está determinada por distintas modalidades narrativas: pasquines, apuntes del Secretario, Cuaderno Privado del Supremo, Circular Perpetua y notas a pie de página de Compilador, dispuestas sin aparente unidad, como textos independientes, pero que sí podrían funcionar como capítulos o apartados. La dimensión del Supremo, es decir la de la trama o anécdota, que es el plano superficial, se inicia con el descubrimiento de un pasquín, elaborado con escritura decimonónica, que fue clavado en la puerta de la catedral, donde se ordena lo que deberá hacer el pueblo una vez que el Supremo muera. Este pasquín funciona como un mandato post mortem que supuestamente el Supremo escribe para determinar lo que sucederá con los oficiales del Estado paraguayo. En él señala: todos los funcionarios deberán ser ahorcados, enterrados en fosa común, y los restos del Supremo incinerados y echados al río. Este pasquín es el leitmotiv de la novela, lo que pone en relación dialógica a los dos actantes principales de la trama: el Supremo y el Secretario Policarpo Patiño. A partir de entonces, uno de los centros de la novela es descubrir al autor del pasquín, y para que los sospechosos confiesen el Supremo manda torturar a todo individuo que le parece misterioso. Incluso sospecha de ratones amaestrados por los contrarrevolucionarios, a quienes, según el Supremo, se les instruyó para pegar el pasquín. Observamos, entonces, que la novela no tiene una estructura novelística canónica, puesto que no hay una focalización precisa en la trama, más bien se trata de una compleja superposición de estructuras discursivas, como bien lo señala Ezquerro.

\section{Oralidad y escritura: dicotomías trascendentes}

Al leer Yo el Supremo observamos que los conflictos recurrentes a lo largo de la novela surgen de una relación dialógica, del contacto entre dicotomías trascendentes, como dominado/dominante, castellano/guaraní, verdadero/falso, vivo/muerto, escritura/oralidad. A partir de ellas, principalmente de la escritura y la oralidad, 
es posible extraer o comprender una poética de la escritura, con la cual no solo puede observarse el hacer de la novela, la revelación del discurso, sino su ideología profunda con respecto al poder, tanto poder político (dictadura, conflicto sociohistórico) como poder escriturario (conflicto lingǘstico y estético).

Dicha poética de la escritura se desprende de la mutua relación de las dicotomías, es decir, de la dialéctica de las voces narrativas principales: Supremo/Secretario, personajes protagónicos de la novela. A su vez, estos personajes representan todas las dialogías expuestas en la novela, en particular simbolizan la oralidad (Supremo) y la escritura (Secretario). Esto es un tanto paradójico, porque el Supremo es quien domina, priva de libertades, niega al pueblo guaraní, pero simboliza la oralidad porque es él quien dicta (en doble sentido: decir y someter), porque se cree revolucionario, crítico social, transgresor, que sin duda lo fue al inicio de sus luchas sociales, pero que sin darse cuenta se fue convirtiendo en un déspota, en un contrarrevolucionario, en un dictador enemigo del pueblo.

El Supremo es la evidencia de la transformación (deformación) política, de la traición a la Revolución, a la lucha social. Por ello, en el transcurso de la diégesis, en un juego de espejos, el Supremo oralidad siempre se estará convirtiendo en el Supremo escritura, Supremo muerte, Supremo traición, artificialidad, imposibilidad, dominación, tortura, aislamiento, putrefacción. Al final de la novela, vemos al Supremo invadido de larvas, tirado su cuerpo en un río, hinchado, con un inevitable rigor mortis encima. En realidad, por los indicios entre líneas a lo largo de la novela, sabemos que el Supremo desde el inicio estuvo muerto, que su voz y su escritura son acciones post mortem. Es decir, fingió ser oralidad, viveza, colectividad, memoria, comunicación del instante (fingió estar vivo), pero en realidad solo era letra muerta, individualidad, aislamiento, egoísmo. ¿Pero acaso eso no se hace en la literatura? El escritor finge, falsea, encubre, disgrega, disimula, selecciona, desfigura, pero sí, también reprueba, reprueba la historia como lo hace Roa Bastos. A partir de estos mecanismos podemos ir reconstruyendo una poética de la escritura, pero también una crítica política a los históricos gobiernos déspotas que han gobernado en Latinoamérica. 
Así, vemos que las relaciones de los binomios se dan por medio de confrontaciones, de luchas de poder, por aparentes enfrentamientos u oposiciones, que se reflejan en la configuración general de la novela. Sin embargo, observamos que las dicotomías no se oponen, solo se complementan, forman parte de un mismo proceso de reflexión.

Nuestra postura es que estas dicotomías no solo se descubren a nivel de la anécdota, sino que repercuten significativamente en el nivel del discurso: en la dimensión espacial, temporal y actancial. Además, son parte esencial de las estrategias textuales de la novela para provocar una particular ideología, relacionada directamente con el propio pensar de la escritura, contra el imperialismo, contra lo que domina (escritura-castellano) y lo que es dominado (oralidad-guaranî). Dice el Supremo: "Parece que ahora no resta más alternativa que apostar al amo inglés o francés y a los que vengan después. Por mi parte no estoy dispuesto a tolerar semejantes marrullerías a ningún imperio sobre la tierra" (473). Critica la lucha por el poder, el colonialismo, la aculturación, la dominación por medio de los discursos de autoridad, por medio de la escritura portadora de la Verdad y lo Absoluto, claro, sin saber que él mismo también lo representa. De igual modo, en la crítica al Poder, el Supremo manifiesta una ruptura cronológica, es decir, traspasa los límites temporales de la anécdota para hacer crítica no solo del pasado, sino del imperio presente, del neocolonialismo: "Armaré una flotilla de barcos cargados hasta el tope. Los pondré bajo su mando y usted no parará hasta la Casa Blanca, quiero decir hasta la Cámara de los Comunes, a presentar esos productos, sus credenciales y mis demandas del reconocimiento de la independencia y soberanía de esta República [Paraguay]" (Yo el Supremo 464-465; énfasis mío). Se usa la ironía como estrategia textual para manifestar una crítica de la situación social actual. Sin duda, aquí se perfila la postura ideológica con la que opera la novela, resultado del juego simbólico de los dobles, incluyendo pasado/presente.

A lo largo de la novela, las dicotomías se confrontan por medio de una relación de poder, una especie de fuerzas contrarias que se oponen para suscitar el pensamiento roabastiano. El poder se 
simboliza de diversas formas en la novela, pero sobre todo es representado por medio de la escritura. La escritura es tratada como un artefacto cultural que ha sido, a lo largo de la historia, instrumento de poder y autoridad. Así, en la relación de poder que se establece entre los personajes de la novela se descubre una postura ideológica, de contenido literario y político: el ejercicio de la escritura, a decir del Supremo, es un artificio contra natura, usado en la dominación de pueblos, por ello ha sido aliada de las dictaduras, de la clase déspotamente gobernante. De esta forma, el poder de la dictadura se convierte en un poder escriturario, en la dictadura de la escritura.

El Supremo termina obsesionado con escribir, día y noche, pero esto se convierte en una condena eterna y atemporal, como la muerte misma. Ello, sin duda, conlleva una postura política y literaria en tanto que revela una crítica mordaz contra el discurso histórico, literario y político oficiales. Además, con ello, de forma implícita propone otra manera de representar o aprehender la realidad, otra que no ha sido oficial, que ha sido relegada, marginada, pero que sin duda para el Supremo es la vía más legítima: la oralidad. Esto se convierte para el Supremo en un proyecto político y literario que va fraguando con una especial manera de entender el poder (de la escritura o del gobierno de un pueblo). Bajo este entendido, el poder (escritura-Gobierno) solo tendrá sentido si involucra la viveza del pueblo, la realidad real de las cosas, las vivencias y dolencias de la gente mostradas a través de la oralidad, es decir, de la vida. La escritura-oralidad (Gobierno-pueblo) será el proyecto liberador que el Supremo emprenderá a lo largo de la novela. Del proceso y resultado de este proyecto observamos la poética de la escritura: reflexión de la escritura en oposición a la oralidad, pero no para derrotar el dominio escritura, sino para manifestar nuevos principios o reglas en que esta debe operar, para así hacer surgir una escritura reivindicada, resemantizada.

Mónica Marinone es una de las críticas que juzga Yo el Supremo no como una novela que desprestigia en todo sentido a la escritura, sino como una novela que busca la "escritura perfecta" conjuntando las dos modalidades de la lengua (oralidad y escritura). Para ella, la práctica narrativa de Roa Bastos es clara: "se trata de representar 
el tiempo en un espacio - la escritura - donde lo visual [grafos]/ acústico [fonos] coexistan interactuando, una zona entre medio que fracture cualquier preferencia sobre una de las modalidades exclusivamente" (Marinone 7). Por esta razón, Marinone señala que Yo el Supremo es una novela hecha para verse y para oírse, para leerse en voz baja y en voz alta, por lo cual propone llamar al receptor o narratario "lector-oyente". Ángel Rama señala que este tipo de literatura busca "la visión regional del mundo, prolongando la vigencia [de la literatura] en una forma aun más rica e interior que antes y así expande la cosmovisión originaria en un modo mejor ajustado, auténtico artísticamente solvente, de hecho modernizado, pero sin destrucción de identidad" (Transculturación 43).

Así, con las diferentes estrategias textuales, se conocerá la naturaleza de la nueva escritura, la cual surgirá con sus propias cualidades, pero también con las ajenas, de tal suerte que el concepto de escritura que se propone estará compuesto de dos elementos: el ego (propio a la grafía) y el alter (propio al fono). De la simbiosis de lo propio y ajeno surgirá una escritura democrática, verdadera por ser más cercana a la realidad, pero utópica por ser una escritura incluyente, descentralizada y no oficiosa.

La escritura se concibe como un artefacto hecho para un fin determinado, en este caso para poner en evidencia los mecanismos de poder: político, lingüístico, literario y cultural. Todo tipo de poder se asume por medio de la escritura, pero al ponerse esta en tela de juicio se pone en duda al poder mismo. El poder, el dictatorial y el escriturario, se desarticula por medio de la ironía y la parodia, razón por la cual la novela está plagada de citas textuales, paráfrasis, hipotextos en general, que tienen por objetivo subvertir humorísticamente el canon histórico y literario. Otra manera de desarmar a la escritura dominante es provocando su reivindicación, manifestando la propuesta de una nueva escritura, la que repare lo que históricamente ha negado: en principio, el discurso oral (la voz del pueblo dominado). Bajo este entendido, Yo el Supremo es la búsqueda de una escritura distinta, diferente a la hegemónica o centrípeta, en la que la pluralidad de voces (polifonía) converjan. 
El proyecto de escritura, que formulamos aquí como una poética roabastiana, puede comprenderse con el concepto de escritura alternativa de Jorge Marcone (1997). Para él, las relaciones entre oralidad y escritura han sido, por muchos años, un asunto de confrontaciones y provocaciones, como si se tratara de dos entidades que se repelen por opuestas la una de la otra. Sin embargo, la escritura alternativa pone de manifiesto la posibilidad de trazar un puente entre el discurso oral y el escrito, ocasionando una dinámica escrituraria específica. Así, para Marcone, la escritura alternativa tiene la capacidad de recrear la experiencia de la comunicación oral, de crear un efecto o ilusión de oralidad con recursos alfabéticos. La escritura alternativa se declara al servicio de la representación del discurso oral, creando una unión entre oralidad y escritura, que significa un intercambio de influencias culturales: la unión del guaraní (lengua nativa del Paraguay que se advierte en la novela) y el castellano, y con ello crea una literatura producto de la transculturación (unión de culturas) y no de la aculturación, como argumentara Ángel Rama. Al mismo tiempo, al ser un proyecto político revolucionario, significa un modo diferente de asumir el poder, de gobernar al pueblo, pues el Supremo entiende que el poder aislado está destinado al fracaso; así la escritura. Una voz externa, la del Compilador quizá, enjuicia:

No busques el fondo de las cosas. No encontrarás la verdad que traicionaste. Te has perdido tú mismo luego de haber hecho fracasar la misma Revolución que quisiste hacer. No intentes purgarte el alma de mentiras. Inútil tanto palabrerío. Muchas otras cosas en las que no has pensado se irán en humo. Tu poder nada puede sobre ellas. Tú no eres tú sino los otros... (falta el folio siguiente). (316)

Con lo anterior no solo deja en evidencia su proyecto de escritura alternativa, sino su propia manera de entender las culturas orales del Paraguay, la forma como han sido desplazadas por la cultura hegemónica española a través de la escritura y el poder. Se trata, sí, de una reivindicación de la oralidad, pero sobre todo de una reivindicación de la escritura. 
El Supremo cuestiona el discurso escriturario, lo reprueba por encontrar en él la historia de la dominación y el poder de pueblos considerados inferiores por practicar la oralidad, por ser culturas ágrafas; critica a la escritura por ser herramienta de los dictadores, de los déspotas ilustrados que gobiernan alejados del pueblo, por ser el medio de someter, de ejercer poder, por considerarla una actividad imperialista y exclusivista. Bajo este entendido, el Supremo inicia su propuesta de escritura alternativa recurriendo al discurso oral, para darle "viveza" a la escritura con los efectos de realidad que dice obtener con el recurso de la palabra hablada. Así busca que la escritura no sea solo un acto individualista y privado, sino una actividad esencialmente social, tal como lo considera Bajtín, quien apunta:

aquello que es individual, que distingue una conciencia de otra y de las demás conciencias, es cognoscitivamente inesencial y es remitido al área de la organización psíquica y a la limitación del espécimen humano. Desde el punto de vista de la verdad, no existe la individualización de las conciencias. El único principio de la individualización cognoscitiva conocido por el individualismo es el error. (Yo también 149-150)

De esta forma, el nuevo concepto de escritura propuesto es un medio abierto, plural, colectivo y descentralizado (por desafiar lo oficial). Esto conlleva una actitud ideológica frente a la historia paraguaya, y latinoamericana en general, pero también frente al material cultural como la literatura. Con estas posturas, a su vez, se comprende el proceso de escritura de la novela (o intento de biografía, como se presenta), pues el Compilador señala:

Esta compilación ha sido entresacada - más honrado sería decir sonsacada - de unos veinte mil legajos, éditos e inéditos; de otros tantos volúmenes, folletos, periódicos, correspondencias y toda suerte de testimonios ocultados, consultados, espigados, espiados, en bibliotecas y archivos privados y oficiales. Hay que agregar a esto las versiones recogidas en las fuentes de la tradición oral, y unas quince mil horas de entrevistas grabadas en magnetófono, agravadas de imprecisiones 
y confusiones, a supuestos descendientes de supuestos funcionarios; a supuestos parientes y contraparientes de El Supremo, que se jactó siempre de no tener ninguno; a epígonos, panegiristas y detractores no menos supuestos y nebulosos. (608)

La biografía del Supremo, irónicamente llamada "compilación", es el resultado de una mezcla de discursos, de una diversidad de fuentes que involucran a la escritura y a la oralidad. Sin embargo, como hemos adelantado, la escritura alternativa no es del todo eficaz, pues el Compilador anota: "En consecuencia, los personajes y hechos que figuran en ellos han ganado, por fatalidad del lenguaje escrito, el derecho a una existencia ficticia y autónoma al servicio del no menos ficticio y autónomo lector" (609; énfasis mío).

La escritura, a pesar de los intentos por reivindicarla, no puede librarse de su propia fatalidad: ser ficticia (en el sentido de fingido, imaginario o falso) y ser autónoma (alejada de la realidad, independiente de la viveza de los sucesos y regida con reglas propias ajenas a la vida misma). Es decir, la escritura no es más que un modo de aprehender la realidad, pero nunca, bajo ningún proceso, podrá ser la realidad misma, ni ejerciéndola con mecanismos de la oralidad, de la vida. Esto se debe a que la oralidad es intraducible, es irreproducible, lo único que puede ser reproducido es lo que tiene qué ver con la escritura (palabras), no con la oralidad misma (gestualidad, tonos, movimientos); la realidad, la historia paraguaya, no puede ser reproducida como si se tratara de un calco. No obstante ser ficticia y autónoma, la escritura tiene una ventaja para el Supremo: "Yo soy el árbitro. Puedo decidir la cosa. Fraguar los hechos. Inventar los acontecimientos. Podría evitar guerras, invasiones, pillajes, devastaciones. Descifrar esos jeroglíficos sangrientos que nadie puede descifrar" (Yo el Supremo 329). En ello se advierte sutilmente su propia forma de entender la literatura, es decir, la escritura. La literatura es un espacio de libertad por ser autónomo, por permitir abiertamente la invención, la imaginación de lo inimaginable, de lo nunca sucedido. Sin embargo, con la poética de la escritura alternativa se manifiesta una crítica al modo tradicional de entender la escritu- 
ra, para posteriormente proponer un nuevo concepto trazado en función de la oralidad.

En la escritura alternativa pueden convivir tanto la oralidad como la escritura. Ambas pueden ser un acto comunicativo más completo, pero a la vez complejo. No obstante, el fracaso se remarca porque la oralidad, en efecto, no puede ser trasladada a la escritura, eso que se traslada en realidad son los aspectos "letrados" de lo oral, pero no es lo oral, lo oral no es el texto, lo oral es lo que es imposible de ser trasladado a escritura, pues lo oral está detrás de esos aspectos lingüísticos. La escritura solo puede reproducir de la oralidad lo que es semejante a ella: los elementos letrados, no todo ese lenguaje extralingüístico que se le escapa a la escritura, como los gestos, las modulaciones, los movimientos corporales, etcétera. Así, aunque la escritura tradicional intente incorporar recursos de la oralidad, con el afán de tener viveza, la realidad representada no es más que un simulacro, una ilusión. Por ello los personajes de la novela reconocen su existencia ficticia, se saben sometidos al juego de la palabra muerta.

A pesar de lo anterior, con la escritura alternativa se desea trasladar la oralidad, no solo el aspecto letrado, sino lo que se conceptualiza por medio de sus prácticas culturales, razón por la cual el personaje encuentra la imposibilidad de su escritura; se convierte en un proyecto fallido en tanto es una escritura utópica, metafórica, meramente simbólica, como meramente utópico es pensar en un Estado popular, no déspota. Ello debido a que atrapar la oralidad en versión escrita es un proyecto imposible; la oralidad no podría expresarse en la escritura sin pérdida de identidad, sin convertirse en otra cosa, simplemente en escritura con una ilusión de oralidad. Escribe el Supremo:

Mas el verdadero lenguaje no nació todavía. Los animales se comunican entre ellos, sin palabras, mejor que nosotros, ufanos de haberlas inventado con la materia prima de lo quimérico. Sin fundamento. Ninguna relación con la vida. ¿Sabes tú, Patiño, lo que es la vida, lo que es la muerte? No; no lo sabes. Nadie lo sabe. No se ha sabido nunca si la vida es lo que 
se vive o lo que se muere. No se sabrá jamás. Además, sería inútil saberlo, admitiendo que es inútil lo imposible. Tendría que haber en nuestro lenguaje palabras que tengan voz. Espacio libre. Su propia memoria. Palabras que subsistan solas, que lleven el lugar consigo. Un lugar. Su lugar. Su propia materia. Un espacio donde esa palabra suceda igual que un hecho. Como en el lenguaje de ciertos animales, de ciertas aves, de algunos insectos muy antiguos. Pero ¿existe lo que no hay? (102)

No obstante, aunque la escritura alternativa no se efectúe, sí hay un cambio en la escritura: es la relegitimación por medio de su discurso crítico que provoca una ideología particular con respecto a la confrontación de lo dominado y lo dominador. La escritura sí expresa un cambio, una transculturación, una hibridación cultural provocada por la conjunción de dos lenguajes distintos e históricamente separados, pero el cambio que sobre todo se advierte al final de la novela es cómo el peso de la autoridad (el poder) se desvanece.

Para Bajtín, en Teoría y estética de la novela, el hecho de fracturar el discurso oficial o tradicional repercute en la consolidación de una nueva escritura: una escritura descentralizada y plurilingüística. Ello desarticula el poder tradicional de la escritura, de la imposición cultural, a su vez, contribuye a preservar una identidad cultural (la guaranî) casi extinta por la dominación de la escritura. Así, la poética de la escritura tiene qué ver con una búsqueda de identidad guaraní y con una reivindicación de la propia escritura, en tanto que con la oralidad se desea representar una interacción social entre individuos, crear una escritura con perspectivas sociales o colectivas (polifónicas). Esto es entender la escritura literaria como un producto cultural construido por la asociación de lo propio (lo paraguayo) y lo ajeno (el castellano). Dice el Supremo:

Voluptuosamente el papel se deja penetrar en las menores hendiduras. Absorbe, chupa la tinta de cada rasgo que lo rasga. Proceso pasional. Conduce a una fusión completa de la tinta con el papel. La mulatez de la tinta se funde con la blancura de 
la hoja. Mutuamente se lubrican los lúbricos. Macho/hembra. Forman ambos la bestia de dos espaldas. He aquí el principio de mezcla. Eh ah no gimas tú, no jadees. No, Señor... no jodo. Sí jodes. Esto es representación. Esto es literatura. Representación de la escritura como representación ... (162)

De esta manera, Yo el Supremo ofrece una nueva escritura, una reinvención de la escritura, donde resuena la oralidad, pero no la oralidad con sus "vicios" de lenguaje (no es el simple calco de palabras nativas, sino la asimilación, como señala Bajtín al respecto), sino una oralidad en un sentido fonético, extraverbal, circular, mnemotécnico, representada por el guaraní, por la manera de expresarse del pueblo paraguayo; ello como un intento por permear la cultura popular ágrafa en una cultura escrituraria, así como también con la idea de acabar con la postura grafocéntrica (de poder), como la única manera de adquirir conocimiento. Al respecto, Bajtín anota: "Las lenguas se iluminan recíprocamente: pues una lengua solo puede verse a sí misma a la luz de otra lengua" (Teoría 457).

Roa Bastos, con el desplazamiento del lenguaje centralizado, logra una estratificación efectiva y un plurilingüismo que da dinamismo en la novela, en términos de Bajtín. La novela representa un contradiscurso a la hegemonía de la escritura y a todas las circunstancias históricas que se han suscitado con ella. Al mismo tiempo, la escritura alternativa, según Marcone, intenta superar la escisión scriptocéntrica entre sujeto y objeto, o sea, eliminar la barrera existente entre el que mira y lo que mira. Así, busca unir la naturalidad del discurso oral con la artificialidad de la escritura: "Lo que te pido, mi estimado Panzancho [de Sancho Panza], es que cuando te dicto no trates de artificializar la naturaleza de los asuntos, sino de naturalizar lo artificioso de las palabras" (Yo el Supremo 158). Se trata de ablandar la dureza de las palabras por su condición artificial y evitar a toda costa su acartonamiento, pues dice el Supremo: "Ya es bien triste que nos veamos reducidos a envasar en palabras, notas, documentos, contradocumentos, nuestros acuerdos-desacuerdos. Encerrar hechos de naturaleza en signos de contranatura" (347). 
Lo anterior solo se logrará al involucrar la oralidad en la escritura, no la escritura en la oralidad; de esta forma para el Supremo las dicotomías quedarían unidas, completadas, mimetizadas: lo subjetivo con lo objetivo, lo individual y personal con lo colectivo y ajeno, lo dominado con lo dominante, etcétera. Ése sería el propósito del Supremo, conseguir que las dualidades se fundan, porque, como este diría, "Todos los seres tiene un doble" (295). Debido a ello, el juego del YO (Supremo) con el Otro (Compilador o Secretario), lo Otro y lo ajeno, es una constante en la novela.

No obstante, el concepto de escritura no solo se formula por medio de la ideología provocada con el juego de los dobles, sino que también se va construyendo a través de la estructura de la novela. Como vimos, el narrador se despliega conformando una diversidad de voces a través de una multiplicidad de discursos; ello tiene sentido en tanto que busca ser una metáfora de lo que se propone como escritura: dejar de ser una práctica individual, de una sola voz, de una perspectiva subjetiva, para asemejarse a la oralidad, que es colectiva, donde concurren diferentes identidades. Los personajes se convierten en una confrontación entre la oralidad y la escritura, y su modo de relacionarse o de interactuar va determinando o construyendo el sentido de escritura. Por su parte, las dimensiones temporales y espaciales son asimiladas y determinadas por el narrador, de tal manera que con ellas se advierte la postura roabastiana sobre la escritura: el Supremo-narrador narra desde la muerte, desde una dimensión atemporal y desde un no-espacio (refiere un presente, pero trastocando tanto un pasado inmediato como el remoto y, al mismo tiempo, modelando un futuro), y al representar él mismo la escritura esta se convierte en cosa muerta, en cosa caduca. González Esteva señala:

el único momento vivo, en el sentido performativo, del lenguaje es el habla. De ahí que la única opción del Supremo, como personaje de una literatura escrita, sea la muerte, el habla póstuma, aquella que sólo revive mediante la lectura y la memoria. De ahí también que el escritor no pueda ser más allá de un compilador de textos, alguien que tan sólo copia y trata de imitar la voz y la vitalidad perdida de la oralidad 
en una escritura muerta, porque no le queda otro remedio más que esperar a ser revivido en la reinterpretación de una lectura, con lo cual ya ni siquiera será lo mismo, pues ya será reinterpretación. (40)

Por esta razón, la propuesta será solo una ilusión, una escritura irrealizable. Entonces, vemos que la mecánica en la que se funde la escritura procede de la totalidad de la novela, de todos sus niveles, como señala Bajtín que debe ser el espacio literario: "la novela como un todo unitario, impregnado de unidad ideológica y de método artístico" (Teoría 318).

Del mismo modo, la transtextualidad contribuye a la determinación del concepto de escritura, pues esta práctica de contacto de hipertextos manifiesta la idea de colectividad (heterogeneidad); y ello es imprescindible para el concepto de escritura, ya que para el Supremo la verdadera escritura se escribe en conjunto: "Los egipcios y los chinos dictaron sus historias a escribientes que soñaban ser el pueblo, no a copistas que estornudaban como tú sobre lo escrito. El pueblo-homero hace una novela. Por tal la dio. Por tal fue recibida" (Yo el Supremo 169). Señala el Supremo: "Es decir, cuantos dijeron YO durante ese tiempo, no eran otros que YO-ÉL, juntos" (425).

La escritura es el resultado de un mecanismo colectivo, no individual. Este modo de concebir la escritura tiene, en el fondo, una postura bajtiniana, en el sentido de entender la novela como una diversidad social, organizada o estratificada por una variedad de voces y lenguas. En la novela se observan discursos intercalados (literarios, como Shakespeare y Miguel de Cervantes; filosóficos, como Voltaire y San Agustín; históricos, como Julio César Chaves, etc.), diferentes lenguas (guaraní, castellano y latinismos), evidencia de clases sociales a través de su universo semántico (palabras decimonónicas, neologismos, términos anacrónicos), entre otros, por medio de los cuales penetra el plurilingüismo en la novela y se perfila una ideología propia. Con esta forma de entender la escritura, Roa Bastos desea representar simbólicamente las clases sociales del Paraguay: la clase privilegiada representada por la escritura y la clase marginada representada por la oralidad. Con la polifonía, es decir 
con la estratificación de voces como recurso narrativo, se evidencia esta crítica social; al confrontar discursos, al carear la oralidad con la escritura, se exhibe la desigualdad social provocada históricamente por el poder.

A su vez, el proceso transtextual tiene como objetivo acentuar la ironía y la parodia, que contribuyen a remarcar la carnavalización de Yo el Supremo, la transgresión del género oficial, hegemónico, centrípeto o unívoco. Al usar hipotextos (por ejemplo, El Quijote), la novela desarrolla una transformación paródica, que da una nueva significación estructural e ideológica. A través de un proceso textual, discursivo, Roa Bastos manifiesta su propia postura ideológica con respecto al poder (político y escriturario) que encierra la escritura, y su consecuente confrontación entre lo dominado y lo dominante. A través de esta reflexión de binomios de fuerzas contrarias, Roa Bastos apuesta por una escritura de resistencia, por una nueva escritura de recuperación de la cultura marginada. En la novela, por tanto, no se busca degradar la escritura, sino reivindicarla, darle un sentido más legítimo, más justo y equitativo, recurriendo como apoyo a la tradición literaria.

La escritura que critica el Supremo es una escritura oficial, unívoca, individualista y, por ello, imperfecta; es pensada como un sistema de comunicación inferior al sistema oral. Sin embargo, en la novela se plantea la inserción de estos dos medios de comunicación para proponer una escritura alternativa que, a fin de cuentas, es una cultura alternativa, la cultura marginada que estuvo minimizada bajo el poder dominante de la escritura y de la ideología provocada por ella. Así, se crea una defensa por la cultura guaraní, olvidada y supeditada a la marginación por la supuesta inferioridad de ser una cultura ágrafa, que no hace uso de la escritura alfabética. De este modo, la oralidad ocupa un espacio en la escritura que nunca antes había podido ocupar por una lucha de poder, en particular político, en tanto la escritura pertenecía a la oligarquía dominadora del Estado, al déspota ilustrado, no al pueblo. La inserción de la oralidad en la cultura oficial, es decir en la escritura, tiene un sentido trascendente: subvertir un discurso, trastocarlo, aniquilar su estado monológico y muerto por ser unidireccional. Con ello, el Supremo 
está convencido de que dará a la escritura una viveza igual a la realidad, igual al diálogo directo.

La reivindicación de la escritura en realidad no se lleva a cabo, pues la oralidad es un medio imposible de asirse, de aprehenderse; sin embargo, sucede algo trascendente: la ideología plasmada en la novela transforma el espacio escriturario, quizá no a nivel del discurso en tanto no hay transformaciones en la estructura hechas por medio de la oralidad, pero sí a nivel del contenido, pues por medio de la polifonía y el dialogismo reivindica la escritura, la vuelve otra al romper con ello un discurso unidireccional u oficial; transgrede el género de la "novela histórica", crea perspectivas narrativas distintas (la dictadura vista desde adentro, a diferencia de cómo se hacía antes), introduce lenguajes creativos (mezcla de guaraní y español), expone un espacio narrativo donde se reflexiona el quehacer literario e histórico, etcétera. Así, aunque en la anécdota sea un fracaso el proyecto de escritura alternativa del Supremo, Roa Bastos, autor implícito, sí logra una escritura creativa al subvertir el discurso formal, al derrotar con su lenguaje y sus juegos dialógicos una escritura hegemónica: no tiene como referente la biografía "oficial" del Dr. Francia, y cuando lo tiene es con intenciones paródicas.

No obstante, si la escritura alternativa resulta un fracaso, ¿fracaso será también la transculturación literaria como empresa indirecta de la conjunción entre oralidad y escritura? Esto implica un concepto de literatura, en particular de literatura latinoamericana, entonces, ¿cómo podemos entender la idea de literatura que se plantea con la imposibilidad de esta simbiosis? Roa Bastos hace una reflexión directa de cómo históricamente se ha implantado la literatura en América Latina y de cómo se ha ido transformando con el paso de los años. Así, entender la poética de la escritura es entender, asimismo, el ejercicio de poder y dominación con la que se introdujo también la literatura, y cómo por muchos años el canon europeo dominó y prevaleció arrogantemente en estas tierras. Pero Roa Bastos cuestiona implícitamente si se derrocó en realidad al canon, si la literatura dominante se subvirtió, o si esta fue mezclada con la cultura lingüística e ideológica propia de la oralidad, es decir, propia de Latinoamérica. Independientemente de la anécdota de Yo 
el Supremo, por el nivel del discurso reconocemos que, en efecto, se trastocó el discurso oficial y se logró, en forma contradictoria, un espacio literario centrífugo y polifónico. Se consiguió, con el tiempo, una literatura transcultural, donde, por supuesto, prevalecen rasgos del canon escriturario, pero con rasgos propios de los pueblos originarios. La literatura latinoamericana se libera del poder, de la dominación, de la histórica dependencia, de las garras de la escritura hegemónica. Bajo este entendido, Roa Bastos, en Yo el Supremo, en un problema particular (exclusivo de Paraguay) devela un problema general, convierte un problema cerrado y unívoco en un asunto abierto y plural. El poder, entonces, queda fracturado no solo porque subvierte el canon literario, sino porque evita reducir la lengua a su simple uso nominalista, individualista, burocrático, exclusivista y dominante.

Asimismo, el poder se desarticula cuando se fractura la relación entre las palabras y las cosas, es decir, cuando la referencialidad se pone en tela de juicio. Además, con ello se cuestionan las pretensiones de la Historia, así como el propósito del Compilador-editor de la biografía del Supremo. El poder de la escritura queda deshecho al truncarse la referencialidad. Con ello queda claro que la escritura es un asunto artificial, engañoso, pues no puede ser referencia exacta del mundo tangible, por ello el Supremo nunca está a favor de la escritura (artificial, muerto, invención) sino de la oralidad (natural, vivo, realidad). Por esa razón, la escritura sería un acto violento y distorsionador de la realidad, una falsa manera de obtener conocimiento del mundo de las cosas.

De este modo, la novela deja explícita la imposibilidad de reproducir tal cual los hechos históricos, ya que la escritura no podrá reflejar los hechos, solo simbolizarlos, representarlos falsamente, vacíamente, razón por la que está condenada a fracasar: a no ofrecer la posibilidad de mostrar con exactitud el mundo. En ello podemos observar el modo de asumir la literatura desde la poética de la escritura roabastiana: la literatura, aún con pretensiones históricas, se escribe con ficción, y no con los recursos de veracidad que presumen tener los historiadores, ya que la escritura no puede develar la realidad bajo términos de verdad absoluta, porque es imposible 
acceder al pasado. Señala González Esteva: “Obviamente, en ese 'historiar ficcionando' se permeará la perspectiva ideológica y filosófica del escritor [Roa Bastos]" (19). La configuración total de la novela revela la perspectiva ideológica con la que ejerce Roa Bastos su oficio.

De esta forma se ponen a prueba las construcciones que se han hecho desde el lenguaje, y que se han dado tácitamente por verdaderas e incuestionables debido al poder que se les ha otorgado histórica y culturalmente. Ángel Rama argumenta que la dominación de la escritura en América comienza después de la Conquista, cuando las ordenanzas, en el proceso de posesión del suelo, reclaman a un escriba "para redactar una escritura":

A ésta se le confería la alta misión que se reservó siempre a los escribanos: dar fe, una fe que solo podía proceder de la palabra escrita, que inició su esplendorosa carrera imperial en el continente. Esta palabra escrita viviría en América Latina como la única valedera, en oposición a la palabra hablada que pertenecía al reino de lo inseguro y lo precario. (La ciudad 22)

No solo la referencialidad está en tela de juicio, la desconfianza en el significado, sino el modo en que adquirimos conocimiento por medio del lenguaje: sistema lingüístico imperfecto, inseguro e inútil y, por tanto, imposible de ofrecer conocimiento de los hechos, de la vida. A menos, como señala el Supremo, que las palabras tengan voz, su propia memoria, autonomía, que se asemejen a la vida o a los hechos. De nueva cuenta se afirma el concepto de escritura ideal. González Esteva comenta que estos cuestionamientos son, en realidad, parte de la problemática de la Historia y la Literatura, de estos dos discursos de poder que han ejercido el lenguaje desde la dominación y que a través de él han pretendido mostrar los sucesos del devenir histórico, en la búsqueda de un significado. Esto, justamente, es lo que se cuestiona en la novela, el modo ideal o perfecto para mostrar el mundo, para asir el mejor significado de las cosas tangibles. La multiplicidad de voces, de modalidades narrativas, de intertextos, de temas, de variedad semántica y lingüística, 
no son más que una metáfora de la polifonía, de los heterogéneos interrogantes que giran en torno al problema de la generación de conocimiento por medio de la oralidad-escritura. González Esteva argumenta que los interrogantes desmontan los discursos dominantes y, además: "Cuestionan desde conceptos que se dan por sentados, como tiempo, realidad, autoridad, hasta la misma forma en que se crean los conceptos y la posibilidad de que sean objetos factibles de ser conocidos" (4). Sin duda, ello se debe, precisamente, al poder con el que se ejerce el espacio de ficción.

La desconfianza en la escritura lleva al Supremo a preferir lo oral. Ve en ello la manifestación de lo humano. Sultán, su alter ego, afirma: "Lo que en el ser humano hay de prodigioso, de temible, de desconocido, no se ha puesto hasta ahora en palabras o en libros, ni se pondrá jamás” (Yo el Supremo 559). Lo oral es también un lenguaje que no puede ser reproducido por ningún soporte material porque implica aspectos comunicativos no verbales. La tradición oral "no se puede saquear, robar, repetir, plagiar, copiar" (Roa Bastos, Yo el Supremo 559).

El lenguaje está intrínsecamente ligado a lo inmaterial: "Lo hablado vive sostenido por el tono, los gestos, los movimientos del rostro, las miradas, el acento, el aliento del que habla" (Roa Bastos, Yo el Supremo 158). El Supremo, debido a ello, critica la escritura, señalando que esta sustrae el aspecto vital (corporal, material, teatral) de la tradición oral. Destaca, además, que la escritura es una técnica que se define por producir copias, falsificaciones, repeticiones, plagios, simulacros, empleando el robo y el saqueo, como irónicamente él lo hace al retrotraer hipotextos de la tradición literaria. González Esteva señala que "la apropiación de los hipotextos históricos supone ya un enfrentamiento al poder de los propios textos, pues pone en evidencia la inclinación ideológica de los mismos" (5). Es una forma de derrocar el poder de dominación del canon literario. Por ello es evidente que la novela es la parodia de varios textos pertenecientes al discurso "hegemónico", pero sin duda el texto central al cual se parodia es El Supremo Dictador (1964) de Julio César Chaves, presidente de la Academia Paraguaya de la Historia y uno de los grandes historiadores de Paraguay. Esta obra es considerada 
la biografía más "objetiva y seria” sobre el Dictador, motivo suficiente para que Roa Bastos cuestione sobre la supuesta verdad con la que se escribe sobre el pasado.

En Yo el Supremo, la escritura es llevada a otro nivel de significancia, es desmontada, es desenmascarada, para reducirla a su desaparición, repetición, y para encontrar en ello su maldición, su tragedia: termina el Supremo siendo una larva destinada a escribir automáticamente, es un autómata de la escritura, sin relación alguna con la realidad de las cosas. Y esta tragedia se debe, como hemos señalado, a la imposibilidad de la oralidad en la escritura, a la imposibilidad del Nosotros en lugar de la individualidad. Es decir, en la escritura no cabe un Nosotros, porque no se puede nunca hablar por el Otro, motivo por el cual el Supremo se traga a sí mismo en la autosuficiencia y encierro de su escritura, en su Yo/Él perpetuo: "Dentro de poco no quedará más que esta mano tiranosauria, que continuará escribiendo, escribiendo, escribiendo, aun fósil, una escritura fósil. Vuelan sus escamas. Se despelleja. Sigue escribiendo" (Yo el Supremo 237).

\section{Conclusiones}

Se trata del sujeto atrapado en el lenguaje. Así, Roa Bastos postula con esta novela cumbre un contradiscurso a la hegemonía de la escritura y a todas las circunstancias históricas que se han suscitado con ella. El personaje refracta una postura ideológica con respecto a la escritura estratificada socialmente a través de una hegemonía indestructible, pero repetitiva y condenada. Por esta razón, la consecuencia de la dictadura escrituraria es un reino de terror, caos y muerte. Asimismo, simboliza los discursos de poder ejercidos por el Estado sobre los pueblos latinoamericanos.

Roa Bastos, al manifestar una lucha entre el poder de la escritura y la subordinación de la oralidad, crea una tonalidad unitaria de la obra por medio de recursos lingüísticos, con lo cual valora no solo el dialecto guaraní, sino la totalidad de esta cultura, cuestionando su supuesta inferioridad y evidenciándola como un fenómeno vivo, que 
perdura en el tiempo a pesar de los múltiples ataques de la cultura dominadora y que es susceptible de transmitir un conocimiento, una memoria colectiva. Además, Roa Bastos asegura: "Es imposible que un escritor paraguayo, en el momento de escribir, pueda prescindir de este doble universo: el exterior [representado por el castellano] y el íntimo [representado por el guaraní], donde luchan sus dos lenguas" (cit. en Ruffinelli 75).

Estos rasgos distintivos de la obra de Roa Bastos lo determinan como escritor de lo latinoamericano, inserto en la nueva narrativa finisecular (siglo xx), que revela una realidad histórica visualizada por medio del sueño, el mito, la fabulación y la "teorización" dentro del espacio de ficción. Así, la producción narrativa de Roa Bastos evidencia a un escritor preocupado por la historia y las luchas del pueblo, con un compromiso social, en función de preceptos ideológicos, pero sin dejar de reconocer la autonomía del arte literario, aunque siempre con sendos puentes dentro de su contexto, como todo producto artístico provocado por la vorágine de la cultura.

\section{Bibliografía}

Bajtín, Mijaíl. Teoría y estética de la novela. Taurus, 1989. . Yo también soy (fragmentos sobre el otro). Taurus, 2000.

Burgos, Fernando. La novela moderna hispanoamericana. Orígenes, 1985.

Burrola Encinas, Rosa María. "Hijo de hombre: entre la Historia y la utopía”. 2006. Universidad Nacional Autónoma de México, Tesis de maestría.

González Esteva, María de la Concepción. Historia y ficción. Una relación de poder en Yo el Supremo, de Augusto Roa Bastos.2011. Universidad Nacional Autónoma de México, Tesis doctoral.

Marcone, Jorge. Oralidad escrita. Sobre la reivindicación y re-inscripción del discurso oral. Pontificia Universidad Católica del Perú, 1997.

Marcos, Juan Manuel. Roa Bastos, precursor del post-boom. Katún, 1983.

Marinone, Mónica. "Redefinir identidades y fronteras: Augusto Roa Bastos y la escritura del nosotros". e-l@tina. Revista electrónica de 
estudios latinoamericanos, vol. 2, no. 7, abril-junio, 2004, pp. 3-11, publicaciones.sociales.uba.ar/index.php/elatina/article/view/ 6224/pdf

Ortega, Julio. El principio radical de lo nuevo. Postmodernidad, identidad y novela en América Latina. Fondo de Cultura Económica, 1998.

Pappe, Silvia. Desconfianza e insolencia. Estudios sobre la obra de Augusto Roa Bastos. Universidad Nacional Autónoma de México / Facultad de Filosofía y Letras /Colegio de Letras, 1987.

Rama, Ángel. La ciudad letrada. Arca, 1998. . Transculturación narrativa en América Latina. Siglo XXI, 1985.

Roa Bastos, Augusto. Yo el Supremo. Cátedra, 2005.

Roa Bastos, Augusto, et al. Augusto Roa Bastos y la producción cultural americana. Ediciones de la Flor / Folios Ediciones, 1986.

Ruffinelli, Jorge. La escritura invisible. Arlt, Borges, García Márquez, Roa Bastos, Rulfo, Cortázar, Fuentes, Vargas Llosa. Universidad Veracruzana, 1986.

Sandoval, Adriana. Los dictadores y la dictadura en la novela bispanoamericana. 1851-1978. Universidad Nacional Autónoma de México, 1989.

Velasco Guerrero, Luis Alfredo. "La novela dialógica latinoamericana: Yo el Supremo". Escritos, vol. 22, no. 48, enero-junio, 2014, pp. 143-167. 